\title{
Expression of the luteinizing hormone receptor (LHR) in ovarian cancer
}

\author{
Shigang Xiong ${ }^{1}$, Paulette Mhawech-Fauceglia², Denice Tsao-Wei ${ }^{3}$, Lynda Roman", Rajesh K. Gaur ${ }^{1}$, \\ Alan L. Epstein ${ }^{5}$ and Jacek Pinski ${ }^{1,3^{*}}$
}

\begin{abstract}
We investigated the association of LHR expression in epithelial ovarian cancer (OC) with clinical and pathologic characteristics of patients. LHR expression was examined immunohistochemically using tissue microarrays (TMAs) of specimens from $232 \mathrm{OC}$ patients. Each sample was scored quantitatively evaluating LHR staining intensity (LHR-I) and percentage of LHR (LHR-P) staining cells in tumor cells examined. LHR-I was assessed as no staining (negative), weak $(+1)$, moderate $(+2)$, and strong positive (+3). LHR-P was measured as 1 to 5,6 to $50 \%$ and $>50 \%$ of the tumor cells examined. Positive LHR staining was found in 202 (87\%) patients' tumor specimens and 66\% patients had strong intensity LHR expression. In 197 (85\%) of patients, LHR-P was measured in > 50\% of tumor cells. LHR-I was significantly associated with pathologic stage $(p=0.007)$. We found that $72 \%$ of stage III or IV patients expressed strong LHR-I in tumor cells. There were $87 \%$ of Silberberg's grade 2 or 3 patients compared to $70 \%$ of grade 1 patients with LHR expression observed in $>50 \%$ of tumor cells, $p=0.037$. Tumor stage was significantly associated with overall survival and recurrence free survival, $p<0.001$ for both analyses, even after adjustment for age, tumor grade and whether patient had persistent disease after therapy or not. Our study demonstrates that LHR is highly expressed in the majority of OC patients. Both LHR-I and LHR-P are significantly associated with either the pathologic stage or tumor grade.
\end{abstract}

\section{Background}

Ovarian cancer (OC) remains the leading cause of death among gynecological malignancies, representing 239,000 patients and resulting in 152,000 deaths every year globally [1]. There is an urgent need to identify prognostic factors in order to better understand the pathogenesis of this deadly disease. The ovaries represent a chief part of the female reproductive system and target for the pituitary hormone, luteinizing hormone (LH). Prior to ovulation, LH triggers a cascade of fundamental events in cell meiosis, mitosis, differentiation, proliferation in ovarian tissue, such as resumption of meiosis of the oocyte, cumulus expansion, rupture of the follicular wall, and extrusion of the cumulus-oocyte mass [2]. Several clinical and epidemiologic studies have implicated reproductive changes

\footnotetext{
* Correspondence: pinski@med.usc.edu

'Department of Medicine/Medical Oncology Division, University of Southern California, 1441 Eastlake Ave, Los Angeles, CA 90033, USA

${ }^{3}$ University of Southern California, Norris Comprehensive Cancer Center, 1441 Eastlake Avenue, Los Angeles, CA 90033, USA

Full list of author information is available at the end of the article
}

with increased risk of $\mathrm{OC}$ which has been associated with menopause [3], the use of fertility drugs [4], and infertility and nulliparity [5]. Moreover, high levels of LH were consistently found in malignant effusions, such as ascites or cystic fluids of OC, as compared to those of nonmalignant ovarian tumor origins $[6,7]$. These observations have led to the hypothesis that pituitary-gonadal signaling may be involved in the carcinogenesis or progression of OC [8].

$\mathrm{LH}$ and human chorionic gonadotropin (hCG) bind to a common transmembrane glycoprotein receptor LHR (or LHCGR), a member of the G protein-coupled receptor family [9], resulting in activation of adenyl cyclase and cAMP production [10]. The expression of LHR mRNA [11], protein, and LHR binding activity [12] have been characterized in $\mathrm{OC}$ and ovarian surface epithelium, the putatively histogenetic origin of the most OCs. Mandai et al. [13] documented expression of LHR mRNA in $55.3 \%$ (26 of 47 ) of OC patient tissue samples while Lenhard et al. showed LHR protein expression by immunohistochemistry in $64.3 \%$ of OC cases [14]. 
Employing in situ hybridization and RT-PCR methods, Lu et al. [15] detected LHR expression in $42 \%$ of benign, $24 \%$ of borderline, and $17 \%$ of malignant ovarian tumors.

Although most studies show positive LHR expression in $\mathrm{OC}$, data on the levels of expression and the role of this receptor in cancer progression are conflicting, limited, and, therefore, require further investigation. In this study, we assessed and quantified the concentration of LHR in a tissue microarray obtained from a large series of patients with $\mathrm{OC}$ who received treatment at our institution between 1991 and 2012 and evaluated the association of the LHR expression with clinical and pathologic characteristics of these patients.

\section{Methods}

\section{Patients and specimens}

Following approval by the Institutional Review Board (IRB), OC patients treated from 1991 to 2012 at the University of Southern California were found in our institutional archives and databases. Patient tissue specimens collected and medical records were collected and retrospectively reviewed under the approved IRB protocol. Patients' age at diagnosis, pathologic stage and grade, outpatient and inpatient treatments, as well as patients' survival and recurrence status, and follow-up information were documented for this study. The tumor histologic subtypes and grade were re-assessed on the hematoxylineosin (H\&E) slides for confirmation by a single experienced pathologist (PMF). The Silverberg grading system was used as the tumor grading system [16].

\section{Tissue microarray construction}

OC tissue microarrays (TMAs) were constructed utilizing archival tissue from eligible patients as described previously [17]. Briefly, A morphologically representative region was carefully selected from the chosen individual paraffin-embedded blocks of OC (donor blocks), followed by a $0.6 \mathrm{~mm}$ core tissue punch biopsy and subsequent transfer to the donor paraffin-embedded block (receiver block). To overcome tumor heterogeneity and tissue loss, 3 core biopsies were performed and extracted from different areas of each tumor. One section was stained with $H \& E$ to evaluate the presence of the tumor by light microscopy.

\section{Immunohistochemistry (IHC) for LHR expression}

The monoclonal anti-human LHR antibody was prepared as described previously $[18,19]$ by Dr. Epstein's laboratory at the University of Southern California. Briefly, the cDNA encoding the human LHR signal and extracellular domains was amplified and fused to the Fc region of human IgG1 by PCR assembling method. The fusion gene then was inserted into the Hind 3 and EcoR1 sites of expression vector $\mathrm{pEE} 12$, resulting in expression vector $\mathrm{pEE} 12 / \mathrm{LHR}$ Fc. The LHR-Fc fusion protein was expressed in NSO murine myeloma cells for long-term stable expression in accordance with the manufacturer's protocol (Lonza Biologics, Portsmouth, NH). The highest producing clone was scaled up for incubation in an aerated 3-L stir flask bioreactor using 5\% dialyzed fetal calf serum (Lonza Biologics, Inc). The fusion protein was then purified from the filtered spent culture medium via tandom Protein-A affinity and ion exchange chromatography. The fusion protein was analyzed by SDS-PAGE to demonstrate proper assembly and purity. Four-week-old BALB/c female mice were injected subcutaneously with recombinant LHR-Fc in complete Freund's adjuvant. Two weeks later, the mice were re-inoculated as above except in incomplete adjuvant. Ten days later, the mice received a third intravenous inoculation of antigen, this time without adjuvant. Four days later, the mice were sacrificed and the splenocytes fused with 8-azaguanine-resistant mouse myeloma NSO cells. Culture supernatants from wells displaying active cell growth were tested via ELISA. Positive cultures were subcloned twice using limiting dilution methods and further characterized by flow cytometry and IHC.

For immunohistochemical studies, $4 \mu \mathrm{m}$ thick sections were deparaffinized with xylene and re-hydrated in graded ethanol solutions. Antibody staining was performed using an ImmPress ${ }^{\text {тм }}$ Excel staining kit according to the manufacturer's instructions (Vector Laboratories, Burlingame, CA). Briefly, antigen retrieval was carried out by treating the deparaffinized sections in citrate buffer (pH 6.0) in a steam-cooker for $20 \mathrm{~min}$. The sections were then incubated $10 \mathrm{~min}$ with $3 \% \mathrm{H}_{2} \mathrm{O}_{2}$ to quench endogenous peroxidase activity followed by blocking with a $2.5 \%$ normal horse serum for $30 \mathrm{~min}$. The slides were then incubated overnight with the above described antibody against LHR (clone 5F4; $1 \mu \mathrm{g} / \mathrm{ml}$ ) along with the horse anti-mouse secondary, then incubated for $45 \mathrm{~min}$ at room temperature. The 3,3'-diaminobenzidine (DAB) was used as a chromogen. Sections were counterstained with hematoxylin and cover slipped. Sections of normal human ovarian tissue was used as positive controls. Negative control slides were included in all assays prepared by staining with secondary antibody only (Additional file 1 and Additional file 2).

\section{LHR expression scoring}

For assessment of LHR expression, the immunostained TMA slides were reviewed and scored by an expert gynecologic pathologist (PMF). A scale of $0-3$ was used to express the extent of IHC reactivity based on the LHR staining intensity (LHR-I) (complete absence of staining, 0 ; weak staining, +1 ; moderate, +2 ; strong, +3 ) and the percentage of LHR stained cells (LHR-P) detected in 
tumor cells examined $(0,<5 \%, 6-50 \%$ and $51-100 \%)$. All other staining patterns were considered negative. Cores were not evaluated if the core was lost, severely damaged, and/or did not have sufficient tumor cellularity. The reviewer was blinded to original histological diagnosis and other clinical data. LHR expression scoring was performed, twice per month, by the same pathologist (PMF).

\section{Statistical analysis}

Standard descriptive statistics were used to summarize baseline and study results. Fisher's exact test was used to test the association of demographics and baseline clinical characteristics with LHR-I and LHR-P detected in tumor cells. Overall survival (OS) was calculated from date of definitive surgery to date of death or latest follow-up. Recurrence free survival (RFS) was calculated from date of definitive surgery to date of recurrence or death from any causes whichever observed first. Kaplan-Meier plots were used to estimate the probabilities of OS and RFS. The associated 95\% confidence intervals were calculated using Greenwood's standard errors formula. Log-rank test was used for testing the association of LHR expression intensity and percent observed in tumor cells, as well as the baseline clinical characteristics with OS and RFS. Cox proportional-hazards model was applied for multivariable analysis. All reported $p$ values were twosided and $p$ values $<0.05$ were considered statistically significant.

\section{Results}

\section{Clinical and pathologic characteristics of patients}

A total of 232 patients diagnosed with primary OC were included in this study. Among these patients, the median age at diagnosis was 58 years (range, $26-89$ years). The histologic subtypes were $69 \%$ serous carcinoma, $9 \%$ endometrioid adenocarcinoma, 7\% clear cell carcinoma, 6\% mucinous carcinoma, $6 \%$ mixed, and $3 \%$ others. The vast majority of these patients $(n=140,60 \%)$ were pathologic stage III and most of them were Silberberg grade $3(76 \%)$, (Table 1). The median duration of follow-up was 68.6 months (range, 0.6-173.3) with median overall survival for all patients of 44.0 months $(95 \% \mathrm{CI}, 39.7,49.9)$. The median recurrence free survival was 26.3 months (95\% CI: $20.9,38.0)$.

\section{Association of LHR intensity (LHR-I) and percentage of LHR expression (LHR-P) with demographic and disease characteristics}

A total of 232 specimens of primary OCs on tissue microarrays (TMAs) were included in the IHC studies. Representative staining patterns (negative, weak, and strong staining) of LHR are illustrated in Fig. 1. The distribution of LHR-I within each histology group is shown in Fig. 2.
As shown in Table 1, LHR was found to be strongly positive in $109 / 160(68 \%)$ cases of serous carcinomas; $13 / 17$ (76\%) cases of clear cell carcinoma, 13/21 (62\%) cases of endometrioid carcinomas, 5/13 (38\%) cases of mucinous carcinoma, and 12/21 (57\%) cases of other types of carcinomas. Among the 232 OC patients, 152 (66\%) showed strong, 26 (11\%) moderate, 24 (10\%) weak staining, and 30 (13\%) complete absence of staining (Table 1). LHR-I was significantly associated with pathologic tumor stage $(p=$ 0.007). We found that $72 \%$ of stage III or IV patients expressed strong LHR-I in tumor cells (Table 2). From these data, $197(85 \%)$ patients had more than $50 \%$ of the cancer cells stained positively for LHR (LHR-P) (Table 1). There were $87 \%$ of Silberberg's grade 2 or 3 patients compared to $70 \%$ of grade 1 patients with LHR expression observed in cases positive with $>50 \%$ of tumor cells, $p=$ 0.037 (Table 3).

\section{Association of overall survival and recurrence free survival with demographic and disease characteristics} Neither LHR intensity (LHR-I) nor the percent of LHR expressing tumor cells (LHR-P) were significantly associated with patient's age at diagnosis, histologic subtypes (serous vs. others), or persistence of disease (Tables 2 and 3). OS and RFS were highly associated with tumor stage, even after adjustment for age at diagnosis, Silberberg's grade, and whether the patient had persistent disease after therapy or not. No significant association was found between OS or RFS with LHR expression intensity (LHR-I) nor the percent of LHR positive tumor cells (LHR-P) (Table 4).

\section{Discussion}

Our results indicate that LHR is not only highly expressed, but also associated with advanced stages and tumor grade of OC. Previously, other groups have documented LHR expression in $\mathrm{OC}$ using different methods of measurement [12-14]. However, most of the aforementioned studies detected LHR in OC at lower concentrations by comparison to this study. This discrepancy could be owing to differences in the sensitivity and specificity of the LHR antibodies and detection kits used, and the associated sample sizes in those studies. Our results are based on a very large number of OC patients (232), allowing for a more representative distribution of histologic subtypes typically seen in the OC populations.

Gonadotropins and their receptor LHR have long been suggested to be involved in the progression of OC. Rapid growth of $\mathrm{OC}$ has been observed during early pregnancy when LH levels are high [20]. It has also been reported [6, 7] that significant concentrations of LH were measured in peritoneal and cystic fluids of women with OC. Moreover, a significant association was observed between high levels of $\mathrm{LH}$ and the degree of malignancy, indicating that 
Table 1 Demographics and baseline disease characteristics

\begin{tabular}{|c|c|c|}
\hline Total Patients & 232 & $100 \%$ \\
\hline Surgery done & $\begin{array}{l}08 / 02 / 91-12 / 13 / \\
12\end{array}$ & \\
\hline \multicolumn{3}{|l|}{ Age at Diagnosis } \\
\hline$<60$ & 130 & $56 \%$ \\
\hline$\geq 60$ & 102 & $44 \%$ \\
\hline Median (Range) & $58(26-89)$ & \\
\hline \multicolumn{3}{|l|}{ Tumor Histology } \\
\hline Serous Carcinoma & 160 & $69 \%$ \\
\hline $\begin{array}{l}\text { Endometrioid } \\
\text { Adenocarcinoma }\end{array}$ & 21 & $9 \%$ \\
\hline Clear Cell Carcinoma & 17 & $7 \%$ \\
\hline Mixed & 15 & $6 \%$ \\
\hline Mucinous Carcinoma & 13 & $6 \%$ \\
\hline MMMT & 4 & $2 \%$ \\
\hline Undifferentiated & 2 & $1 \%$ \\
\hline \multicolumn{3}{|l|}{ Pathologic Stage } \\
\hline । & 50 & $22 \%$ \\
\hline$\|$ & 18 & $8 \%$ \\
\hline III & 140 & $60 \%$ \\
\hline IV & 24 & $10 \%$ \\
\hline \multicolumn{3}{|l|}{ Silberberg's Grade } \\
\hline 1 & 27 & $12 \%$ \\
\hline 2 & 28 & $12 \%$ \\
\hline 3 & 177 & $76 \%$ \\
\hline \multicolumn{3}{|l|}{ Received Chemotherapy } \\
\hline No & 16 & $7 \%$ \\
\hline Yes & 216 & $93 \%$ \\
\hline \multicolumn{3}{|l|}{ Residual Disease } \\
\hline No & 113 & $49 \%$ \\
\hline Yes & 119 & $51 \%$ \\
\hline \multicolumn{3}{|l|}{ Persistent Disease } \\
\hline No & 144 & $62 \%$ \\
\hline Yes & 88 & $38 \%$ \\
\hline \multicolumn{3}{|l|}{ LHR-I } \\
\hline Negative & 30 & $13 \%$ \\
\hline Weak & 24 & $10 \%$ \\
\hline Moderate & 26 & $11 \%$ \\
\hline Strong & 152 & $66 \%$ \\
\hline \multicolumn{3}{|l|}{ LHR-P } \\
\hline $0 \%$ & 30 & $13 \%$ \\
\hline $1-50 \%$ & 4 & $2 \%$ \\
\hline$>50 \%$ & 197 & $85 \%$ \\
\hline Missing/LHR Intensity Negative & 1 & \\
\hline Tumor Histology & \multicolumn{2}{|c|}{ LHR Expression Intensity } \\
\hline
\end{tabular}

Table 1 Demographics and baseline disease characteristics (Continued)

\begin{tabular}{lcclll}
\hline Serous Carcinoma & 160 & $16(10 \%)$ & $\begin{array}{l}19 \\
(12 \%)\end{array}$ & $16(10 \%)$ & $\begin{array}{l}109 \\
(68 \%)\end{array}$ \\
$\begin{array}{l}\text { Endometrioid } \\
\text { Adenocarcinoma }\end{array}$ & 21 & $3(14 \%)$ & $\begin{array}{l}2 \\
(10 \%)\end{array}$ & $3(14 \%)$ & $\begin{array}{l}13 \\
(62 \%)\end{array}$ \\
Clear Cell Carcinoma & 17 & $0(0 \%)$ & $0(0 \%)$ & $4(24 \%)$ & $\begin{array}{l}13 \\
(76 \%)\end{array}$ \\
Mixed & 15 & $4(27 \%)$ & $1(7 \%)$ & $3(20 \%)$ & $7(47 \%)$ \\
Mucinous Carcinoma & 13 & $6(46 \%)$ & 2 & $0(0 \%)$ & $5(38 \%)$ \\
MMMT & 4 & $1(25 \%)$ & $0(0 \%)$ & $0(0 \%)$ & $3(75 \%)$ \\
Undifferentiated & 2 & $0(0 \%)$ & $0(0 \%)$ & $0(0 \%)$ & 2 \\
& & & & & $(100 \%)$
\end{tabular}

gonadotropins may promote progression of LHR-positive $\mathrm{OC}$. The incidence of $\mathrm{OC}$ has been shown to be increased under clinical conditions with elevated gonadotropins such as during menopause [3], infertility and nulliparity [5], or in women who receive induction treatment for ovulation [4, 21]. In contrast, reduced risk of OC was paired with clinical conditions associated with lower levels and reduced exposure to gonadotropins, such as multiple pregnancies, breast feeding, oral contraceptives, and estrogen replacement therapy $[4,5]$.

Several in vitro studies also support the stimulatory role of gonadotropins in the carcinogenesis and progression of OC. In studies with ovarian surface epithelium, a possible histogenetic origin of $\mathrm{OC}$, treatment with $\mathrm{hCG}$ stimulated the proliferation of cells in a dose-dependent manner [12, 22]. Many in vitro studies on OC cell lines reported a stimulatory effect of LH/hCG on cell growth [23-25]. hCG stimulated (3H)-thymidine incorporation into DNA in LHR-expressing cells of normal ovarian surface epithelium (OSE) and the OC cell line OCC1, but not in LHR negative SKOV3 cells [24], suggesting that the stimulating effect of $\mathrm{LH}$ on OC is LHRdependent. On the other hand, other groups of investigators demonstrated an inhibitory effect of LH on OC cell proliferation and release of CA-125 [26]. These conflicting findings could be explained by the different cell lines, in vitro conditions and concentrations of $\mathrm{LH}$ used in those studies. In addition to affecting OC cell proliferation, LH has also been shown to influence cellular processes, including adhesion [27], anchorage-independent growth [25], angiogenesis [28] and apoptosis [12, 23]. In animal models, OC could be induced after prolonged treatment with exogenous gonadotropins or elevated levels of endogenous gonadotropins [29]. In inhibin-alpha-deficient mice, gonadotropins were essential for gonadal and adrenal tumorigenesis [30], and chronically elevated circulating levels of LH or hCG caused ovarian and extragonadal tumors in certain strains of mice [31], strongly supporting the carcinogenic effect of gonadotropins on their target 


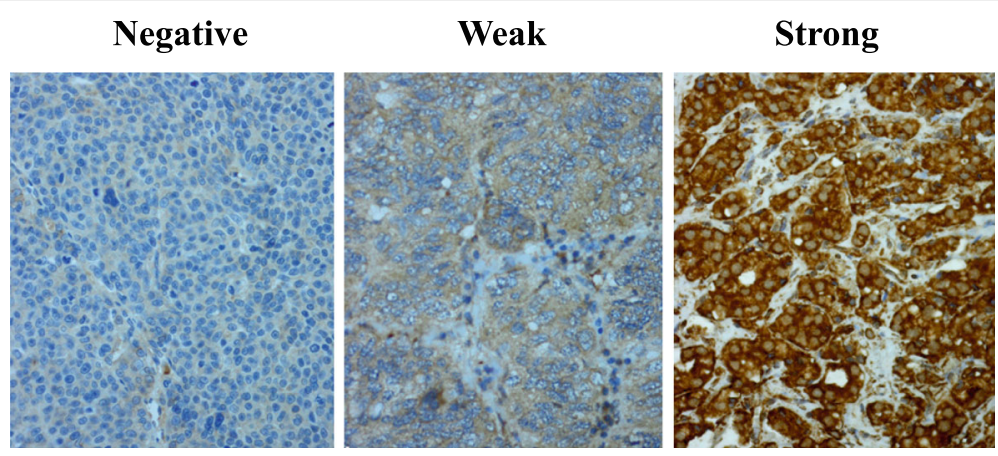

Fig. 1 Expression of LHR protein in the specimens of primary epithelial OC on TMAs. Representative staining patterns of LHR immunohistochemical reactivity (negative, weak and strong) are presented (400X)

organs. $\mathrm{LH}$ is responsible for inducing ovulation in premenopausal women. The ovulatory process involves extensive proteolytic activity, cell proliferation, and tissue healing and remodeling, which parallels many cancerassociated processes [32].

Apoptosis is an important brake mechanism for carcinogenesis and cancer progression. It has been shown that hCG not only stimulates cell proliferation but also suppresses apoptosis in LHR-expressing cells of the OSE. This anti-apoptotic signaling of hCG was mediated by the insulin-like growth factor-1(IGF-1)/IGF-1 receptor pathway [12]. hCG treatment also demonstrated a LHR-dependent inhibition of cisplatin-induced apoptosis in LHR-positive OVCAR-3, but not in LHR-negative

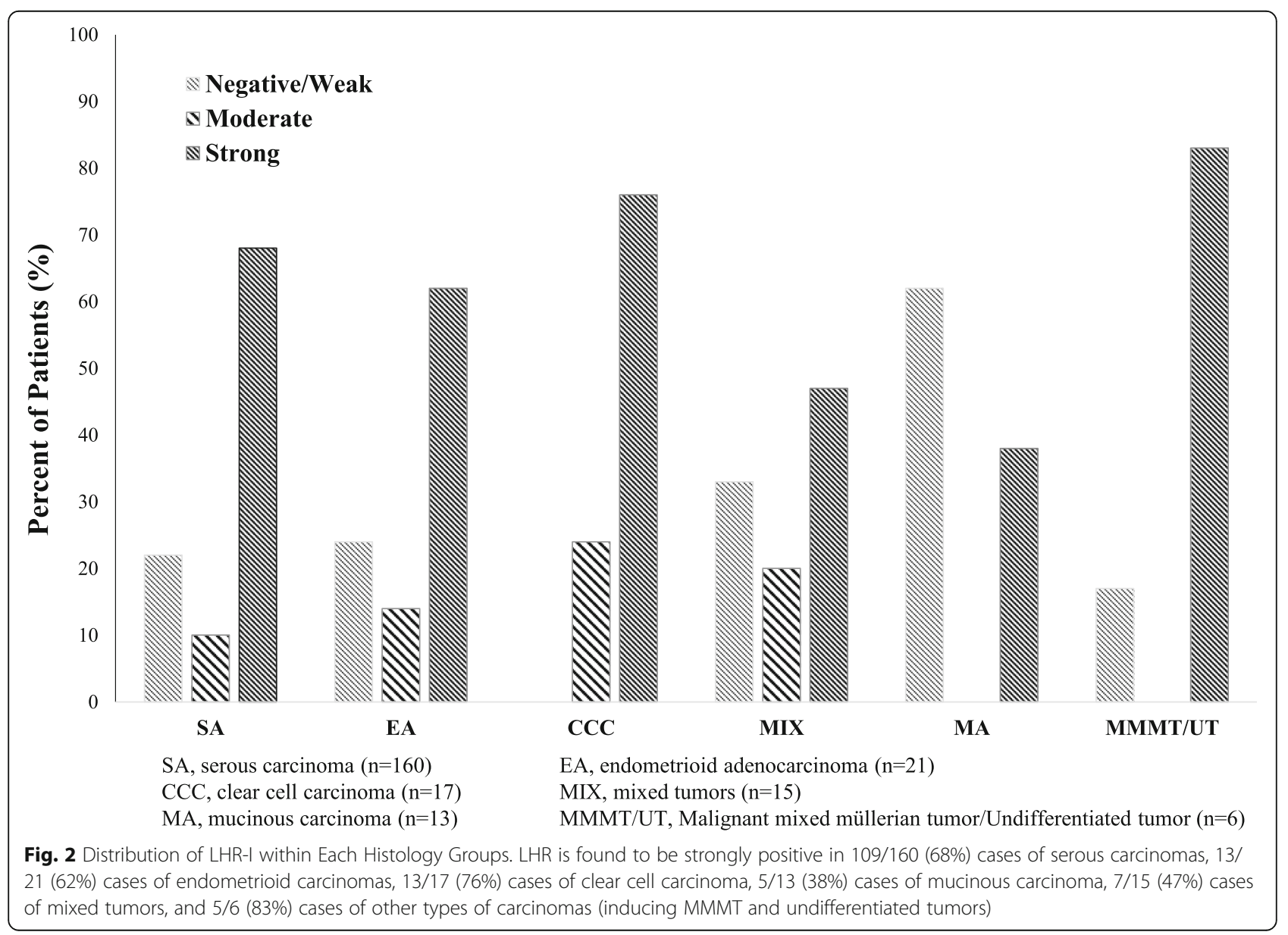


Table 2 Association of LHR-I with demographics and disease characteristics

\begin{tabular}{|c|c|c|c|c|c|c|}
\hline \multirow[t]{2}{*}{ Factors } & \multirow[t]{2}{*}{ N } & \multicolumn{4}{|c|}{ LHR Intensity } & \multirow[t]{2}{*}{$p$-value* } \\
\hline & & Negative & Weak & Moderate & Strong & \\
\hline \multicolumn{7}{|c|}{ Age at Diagnosis } \\
\hline$<60$ & 130 & $21(16 \%)$ & 15 (12\%) & 16 (12\%) & 78 (60\%) & \multirow[t]{2}{*}{0.22} \\
\hline$\geq 60$ & 102 & $9(9 \%)$ & $9(9 \%)$ & $10(10 \%)$ & 74 (73\%) & \\
\hline \multicolumn{7}{|c|}{ Serous Carcinoma } \\
\hline No & 72 & 14 (19\%) & $5(7 \%)$ & $10(14 \%)$ & $43(60 \%)$ & \multirow[t]{2}{*}{0.13} \\
\hline Yes & 160 & $16(10 \%)$ & 19 (12\%) & 16 (10\%) & 109 (68\%) & \\
\hline \multicolumn{7}{|c|}{ Pathologic Stage } \\
\hline$|/| \mid$ & 68 & 13 (19\%) & $8(12 \%)$ & 13 (19\%) & $34(50 \%)$ & \\
\hline III/IV & 164 & $17(10 \%)$ & $16(10 \%)$ & $13(8 \%)$ & $118(72 \%)$ & \\
\hline \multicolumn{7}{|c|}{ Silberberg's Grade } \\
\hline 1 & 27 & $7(26 \%)$ & $3(11 \%)$ & $2(7 \%)$ & 15 (56\%) & \multirow[t]{2}{*}{0.21} \\
\hline 2 or 3 & 205 & $23(11 \%)$ & $21(10 \%)$ & $24(12 \%)$ & 137 (67\%) & \\
\hline \multicolumn{7}{|c|}{ Persistent Disease } \\
\hline No & 144 & $22(15 \%)$ & 15 (10\%) & 17 (12\%) & 90 (63\%) & \multirow[t]{2}{*}{0.53} \\
\hline Yes & 88 & $8(9 \%)$ & $9(10 \%)$ & $9(10 \%)$ & $62(70 \%)$ & \\
\hline
\end{tabular}

${ }^{*} p$-value based on Fisher's exact test

SK-OV-3 cells, suggesting a LHR-dependent inhibition via up-regulation of IGF-1. In addition, LH prevented cisplatin-induced apoptosis in oocytes [33]. During cyclic ovulation when the OSE is exposed to repeated injury and healing processes, apoptosis is likely to represent a

Table 3 Association of LHR-P with demographics and disease characteristics

\begin{tabular}{|c|c|c|c|c|}
\hline \multirow[t]{2}{*}{ Factors } & \multirow[t]{2}{*}{$N^{a}$} & \multicolumn{2}{|c|}{ LHR Expression Observed in Tumor Cells } & \multirow[t]{2}{*}{$p$-value* } \\
\hline & & $\leq 50 \%$ & $>50 \%$ & \\
\hline \multicolumn{5}{|c|}{ Age at Diagnosis } \\
\hline$<60$ & 130 & $24(18 \%)$ & $106(82 \%)$ & \multirow[t]{2}{*}{0.09} \\
\hline$\geq 60$ & 101 & $10(10 \%)$ & $91(90 \%)$ & \\
\hline \multicolumn{5}{|l|}{ Histology } \\
\hline Serous & 159 & $19(12 \%)$ & $140(68 \%)$ & \multirow[t]{2}{*}{0.11} \\
\hline Other & 72 & $15(21 \%)$ & $57(79 \%)$ & \\
\hline \multicolumn{5}{|c|}{ Pathologic Stage } \\
\hline$|/| \mid$ & 68 & $15(22 \%)$ & $53(78 \%)$ & \multirow[t]{2}{*}{0.065} \\
\hline III/IV & 163 & $19(12 \%)$ & $144(88 \%)$ & \\
\hline \multicolumn{5}{|c|}{ Silberberg's Grade } \\
\hline 1 & 27 & $8(30 \%)$ & $19(70 \%)$ & \multirow[t]{2}{*}{0.037} \\
\hline 2 or 3 & 204 & $26(13 \%)$ & $178(87 \%)$ & \\
\hline \multicolumn{5}{|c|}{ Persistent Disease } \\
\hline No & 143 & $25(17 \%)$ & $118(83 \%)$ & \multirow[t]{2}{*}{0.18} \\
\hline Yes & 88 & 9 (10\%) & 79 (90\%) & \\
\hline
\end{tabular}

ane patient doesn't have LHR expression observed in tumor cell data available

${ }^{*} p$-value based on Fisher's exact test
Table 4 Association of Overall Survival and Recurrence Free Survival with Demographics and Disease Characteristics

\begin{tabular}{|c|c|c|c|c|c|}
\hline \multirow[t]{2}{*}{ Factors } & \multirow[t]{2}{*}{$\mathrm{N}$} & \multicolumn{2}{|c|}{$\begin{array}{l}\text { Overall Survival } \\
\text { (Months) }\end{array}$} & \multicolumn{2}{|c|}{$\begin{array}{l}\text { Recurrence Free } \\
\text { Survival (Months) }\end{array}$} \\
\hline & & $\begin{array}{l}\text { Median } \\
(95 \% \mathrm{Cl})\end{array}$ & $p$-value* & $\begin{array}{l}\text { Median } \\
(95 \% \mathrm{Cl})\end{array}$ & $p$-value* \\
\hline Overall & 232 & $\begin{array}{l}44.0 \text { (39.7, } \\
49.9)\end{array}$ & & $\begin{array}{l}26.3(20.9, \\
38.0)\end{array}$ & \\
\hline Age at Diagnosis & & & $<0.001$ & & $<0.001$ \\
\hline$<60$ & 130 & $\begin{array}{l}52.2(45.0, \\
84.9)\end{array}$ & $0.18 \wedge$ & $\begin{array}{l}38.0(22.3, \\
49.9)\end{array}$ & $0.26 \wedge$ \\
\hline$\geq 60$ & 102 & $\begin{array}{l}36.8(25.1, \\
41.8)\end{array}$ & & $\begin{array}{l}22.0(15.3, \\
26.6)\end{array}$ & \\
\hline Pathologic Stage & & & $<0.001$ & & $<0.001$ \\
\hline$|/| \mid$ & 68 & $\begin{array}{l}\text { Not } \\
\text { reached }\end{array}$ & $\begin{array}{l}< \\
0.001 \wedge\end{array}$ & $\begin{array}{l}\text { Not } \\
\text { reached }\end{array}$ & $\begin{array}{l}< \\
0.001 \wedge\end{array}$ \\
\hline III/IV & 140 & $\begin{array}{l}38.0(30.1, \\
41.8)\end{array}$ & & $\begin{array}{l}20.0(16.6, \\
24.2)\end{array}$ & \\
\hline Silberberg's Grade & & & $<0.001$ & & $<0.001$ \\
\hline 1 & 27 & $\begin{array}{l}\text { Not } \\
\text { reached }\end{array}$ & $0.23 \wedge$ & $\begin{array}{l}\text { Not } \\
\text { reached }\end{array}$ & $0.060 \wedge$ \\
\hline 2 or 3 & 205 & $\begin{array}{l}41.8(37.9, \\
45.9)\end{array}$ & & $\begin{array}{l}24.2(19.1, \\
29.9)\end{array}$ & \\
\hline Persistent Disease & & & $<0.001$ & & $<0.001$ \\
\hline No & 144 & $\begin{array}{l}69.8(52.2, \\
85.7)\end{array}$ & $\begin{array}{l}< \\
0.001 \wedge\end{array}$ & $\begin{array}{l}35.8(20.9, \\
51.4)\end{array}$ & $0.69 \wedge$ \\
\hline Yes & 88 & $\begin{array}{l}24.2(15.3, \\
30.5)\end{array}$ & & $\begin{array}{l}24.2(15.3, \\
30.5)\end{array}$ & \\
\hline LHR-I & & & 0.28 & & 0.27 \\
\hline $\begin{array}{l}\text { Negative/Weak/ } \\
\text { Moderate }\end{array}$ & 80 & $\begin{array}{l}51.2(40.7, \\
65.9)\end{array}$ & & $\begin{array}{l}29.9(19.0, \\
46.0)\end{array}$ & \\
\hline Strong & 152 & $\begin{array}{l}41.9 \text { (38.0, } \\
45.3)\end{array}$ & & $\begin{array}{l}24.5(19.6, \\
38.0)\end{array}$ & \\
\hline LHR-P & & & 0.36 & & 0.53 \\
\hline$\leq 50 \%$ & 34 & $\begin{array}{l}50.3(35.4 \\
74.3)\end{array}$ & & $\begin{array}{l}36.0(19.0, \\
50.3)\end{array}$ & \\
\hline$>50 \%$ & 197 & $\begin{array}{l}43.8(39.2, \\
49.5)\end{array}$ & & $\begin{array}{l}24.6(20.0, \\
38.0)\end{array}$ & \\
\hline
\end{tabular}

${ }^{*} p$-value based on logrank test

$\wedge p$-value based on Wald test from Cox proportional model, adjusted by all other variables with $p<0.05$ in univariate analysis

protective mechanism by which injured cells are being eliminated. It is therefore possible that excessive stimulation of LH/hCG may enhance the susceptibility of OSE to carcinogenesis.

Despite the progress made with regard to diagnosis and treatment over the last years, $\mathrm{OC}$ remains a major cause of mortality [1]. Since expression of LHR can be found in most specimens, LH receptors might represent targets for immunotherapy or cytotoxic conjugated agents that can exploit these receptors to deliver hybridized cytotoxic moieties. Successful attempts have been made in animal experiments with hCG-hecate conjugates [34]. 


\section{Conclusions}

Our study demonstrates that LHR is not only strongly expressed in the vast majority of OC specimens of different histology subtypes but it is also significantly associated with advanced tumor grades and pathologic stages of this disease. Further studies are needed to explore the role LHR in the carcinogenesis and progression of $\mathrm{OC}$ and to exploit the presence of this receptor as a target for novel therapies against $\mathrm{OC}$.

\section{Supplementary information}

Supplementary information accompanies this paper at https://doi.org/10. 1186/s12885-019-6153-8.

Additional file 1: Figure S1. Western blot was performed with antiLHR antibody (5F4) in HepG2 (positive) and LNCaP (positive) cell lines and were able to clearly show the about $85 \mathrm{kDa}$ band for LHR expression. For the negative controls, CHO-K1 and DU145 cell lines were used, showing no LHR expression in both cell lines.

Additional file 2: Figure S2. Immunohistochemistry was performed with anti-LHR antibody (5F4) on the slides of normal human tissues (colon, liver and lung) as negative controls, showing no LHR immunoactivity in these tissues.

\section{Abbreviations}

hCG: Human chorionic gonadotropin; IHC: Immunohistochemistry; LH: Luteinizing hormone; LHR: Luteinizing hormone receptor; LHR-I: LHR staining intensity; LHR-P: Percentage of LHR stained cells in tumor cells examined; OC: Ovarian cancer; OS: Overall survival; OSE: Normal ovarian surface epithelium; RFS: Recurrence free survival; TMAs: Tissue microarrays

\section{Acknowledgements}

The authors thank the support of Cell BT, Inc. for this study.

\section{Authors' contributions}

JP conceived the study idea, interpreted the data, wrote and revised the manuscript. SX and AE participated in the design, coordination of the study, interpreted the data, and wrote and revised the manuscript. SX, PMF, LR, and RG collected the materials and conducted data extraction. DT analyzed and interpreted the data and revised the manuscript. All authors contributed to improving the manuscript for publication. All authors read and approved the final manuscript.

\section{Funding}

This work was supported by Cell BT, Inc. (Cell Biotherapy), Los Angeles, CA. for the design of the study and collection, analysis, and interpretation of data and writing the manuscript.

\section{Availability of data and materials}

All data and materials generated or analyzed during this study are included in this published article.

\section{Ethics approval and consent to participate}

This study was approved by the Institutional Review Board (IRB) of the University of Southern California. The written informed consent to participate in the study was be obtained from all participants. No animal was involved in this study.

\section{Consent for publication}

Not applicable

\section{Competing interests}

Dr. Pinski and Dr. Epstein are the co-founders of Cell BT, Inc. All other authors declare that they have no competing interests.

\section{Author details}

${ }^{1}$ Department of Medicine/Medical Oncology Division, University of Southern California, 1441 Eastlake Ave, Los Angeles, CA 90033, USA. ${ }^{2}$ Aurora Diagnostics, Department of Pathology, Gynecologic Pathology Consultant, San Antonio, TX 78209, USA. ${ }^{3}$ University of Southern California, Norris Comprehensive Cancer Center, 1441 Eastlake Avenue, Los Angeles, CA

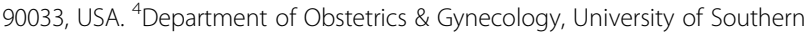
California Keck School of Medicine, Los Angeles, CA 90033, USA.

${ }^{5}$ Department of Pathology, University of Southern California, HMR 2011 Zonal Ave, Los Angeles, CA 90033, USA.

Received: 29 March 2019 Accepted: 11 September 2019

Published online: 15 November 2019

\section{References}

1. Reid BM, Permuth JB, Sellers TA. Epidemiology of ovarian cancer: a review. Cancer Biol Med. 2017;14:9-32.

2. Amsterdam A, Rotmensch S. Structure-function relationships during granulosa cell differentiation. Endocrinol Rev. 1987;8:309-37.

3. Chakravarti S, Collins WP, Forecast JD, Newton JR, Oram DH, Studd JW. Hormonal profiles after the menopause. Br Med J. 1976;2:748-87.

4. Whittemore AS, Harris R, Itnyre J. Characteristics relating to ovarian cancer risk: collaborative analysis of 12 US case-control studies. II. Invasive epithelial ovarian cancers in white women. Am J Epidemiol. 1992;136:1184-203.

5. Ness RB, Cramer DW, Goodman MT, et al. Infertility, fertility drugs, and ovarian cancer: a pooled analysis of case-control studies. Am J Epidemiol. 2002;155:217-24.

6. Halperin R, Pansky M, Vaknin Z, Zehavi S, Bukovsky I, Schneider D. Luteinizing hormone in peritoneal and ovarian cyst fluids: a predictor of ovarian carcinoma. Eur J Obstet Gynecol Reprod Biol. 2003;110:207-10.

7. Chudecka-Glaz A, Rzepka-Gorska I, Kosmowska B. Gonadotropin (LH, FSH) levels in serum and cyst fluid in epithelial tumors of the ovary. Arch Gynecol Obstet. 2004;270:151-6.

8. Leung PC, Choi JH. Endocrine signaling in ovarian surface epithelium and cancer. Hum Reprod Update. 2007;13:143-62.

9. McFarland KC, Sprengel R, Phillips HS, et al. Lutropin choriogonadotropin receptor: an unusual member of the $\mathrm{G}$ protein-coupled receptor family. Science. 1989;245:494-9.

10. Kammerman S, Demopoulos RJ, Raphael CR, Ross J. Gonadotropic hormone binding to human ovarian tumors. Hum Pathol. 1981;12:886-90.

11. Nishimori K, Dunkel L, Hsueh AJW, Yamoto M, Nakano R. Expression of luteinizing hormone and chorionic gonadotropin receptor messenger ribonucleic acid in human corpora lutea during menstrual cycle and pregnancy. J Clin Endocrinol Metab. 1995;80:1444-8.

12. Kuroda H, Mandai M, Konishi I, et al. Human ovarian surface epithelial (OSE) cells express LH/hCG receptors, and hCG inhibits apoptosis of OSE cells via up-regulation of insulin-like growth factor-1. Int J Cancer. 2001;91:309-15.

13. Mandai $\mathrm{M}$, Konishi I, Kuroda $\mathrm{H}$, et al. Messenger ribonucleic acid expression of $\mathrm{LH}$ / hCG receptor gene in human ovarian carcinomas. Eur J Cancer. 1997;33:1501-7.

14. Lenhard M, Lennerová T, Ditsch N, et al. Opposed roles of folliclestimulating hormone and luteinizing hormone receptors in ovarian cancer survival. Histopathology. 2011;58:990-4.

15. Lu JJ, Zheng Y, Kang X, et al. Decreased luteinizing hormone receptor mRNA expression in human ovarian epithelial cancer. Gynecol Oncol. 2000; 79:158-68.

16. Malpica A, Deavers MT, Lu K, et al. Grading ovarian serous carcinoma using a two-tier system. Am J Surg Pathol. 2004;28:496-504.

17. Mhawech-Fauceglia P, Wang D, Kim G, et al. Expression of DNA repair proteins in endometrial cancer predicts disease outcome. Gynecol Oncol. 2014;132:593-8.

18. Zhang N, Sadun RE, Arias RS, et al. Targeted and untargeted CD137L fusion proteins for the immunotherapy of experimental solid tumors. Clin Cancer Res. 2007;13:2758-67.

19. Sadun RE, Hsu WE, Zhang N, et al. Fc-mOX40L fusion protein produces complete remission and enhanced survival in 2 murine tumor models. J Immunother. 2008:31:235-45.

20. Kobayashi F, Monma C, Nanbu K, Konishi I, Sagawa N, Mori T. Rapid growth of an ovarian clear cell carcinoma expressing $\mathrm{LH} / \mathrm{hCG}$ receptor arising from endometriosis during early pregnancy. Gynecol Oncol. 1996;62:309-13.

21. Ozols RF, Bookman MA, Connolly DC, et al. Focus on epithelial ovarian cancer. Cancer Cell. 2004;5:19-24. 
22. Osterholzer HO, Streibel EJ, Nicosia SV. Growth effects of protein hormones on cultured rabbit ovarian surface epithelial cells. Biol Reprod. 1985;33:247-58.

23. Kuroda H, Mandai M, Konishi I, et al. Human chorionic gonadotropin (hCG) inhibits cisplatin-induced apoptosis in ovarian cancer cells: possible role of up-regulation of insulin-like growth factor-1 by hCG. Int J Cancer. 1998;76: 571-8.

24. Parrott JA, Doraiswamy V, Kim G, Mosher R, Skinner MK. Expression and actions of both the follicle stimulating hormone receptor and the luteinizing hormone receptor in normal ovarian surface epithelium and ovarian cancer. Mol Cell Endocrinol. 2001;172:213-22.

25. Tashiro H, Katabuchi $\mathrm{H}$, Begum M, et al. Roles of luteinizing hormone/ chorionic gonadotropin receptor in anchorage-dependent and -independent growth in human ovarian surface epithelial cell lines. Cancer Sci. 2003;94:953-9.

26. Kurbacher CM, Jager W, Kurbacher JA, Bittl A, Wildt L, Lang N. Influence of human luteinizing hormone on cell growth and CA 125 secretion of primary epithelial ovarian carcinomas in vitro. Tumour Biol. 1995;16:374-84

27. Schiffenbauer YS, Meir G, Maoz M, Even-Ram SC, Bar-Shavit R, Neeman M. Gonadotropin stimulation of MLS human epithelial ovarian carcinoma cells augments cell adhesion mediated by CD44 and by a(v)-integrin. Gynecol Oncol. 2002;84:296-302.

28. Zygmunt M, Herr F, Keller-Schoenwetter S, et al. Characterization of human chorionic gonadotropin as a novel angiogenic factor. J Clin Endocrinol Metab. 2002;87:5290-6.

29. Kammerman S, Demopoulos RI, Ross J. Gonadotropin receptors in experimentally induced ovarian tumors in mice. Cancer Res. 1977;37:2578-82.

30. Kumar TR, Wang Y, Matzuk MM. Gonadotropins are essential modifier factors for gonadal tumor development in inhibin-deficient mice. Endocrinology. 1996;137:4210-6.

31. Rulli SB, Kuorelahti A, Karaer O, Pelliniemi L, Poutanen M, Huhtaniemi I. Reproductive disturbances, pituitary lactotrope adenomas, and mammary gland tumors in transgenic female mice producing high levels of human chorionic gonadotropin. Endocrinology. 2002;143:4085-95.

32. Curry TE Jr, Osteen KG. The matrix metalloproteinase system: changes, regulation, and impact throughout the ovarian and uterine reproductive cycle. Endocr Rev. 2003;24:428-65.

33. Rossi V, Lispi M, Longobardi S, et al. LH prevents cisplatin-induced apoptosis in oocytes and preserves female fertility in mouse. Cell Death Differ. 2017; 24:72-82.

34. Bodek G, Vierre S, Rivero-Müller A, Huhtaniemi I, Ziecik AJ, Rahman NA. A novel targeted therapy of Leydig and granulosa cell tumors through the luteinizing hormone receptor using a hecate-chorionic gonadotropin beta conjugate in transgenic mice. Neoplasia. 2005;7:497-508.

\section{Publisher's Note}

Springer Nature remains neutral with regard to jurisdictional claims in published maps and institutional affiliations.

\section{Ready to submit your research? Choose BMC and benefit from:}

- fast, convenient online submission

- thorough peer review by experienced researchers in your field

- rapid publication on acceptance

- support for research data, including large and complex data types

- gold Open Access which fosters wider collaboration and increased citations

- maximum visibility for your research: over $100 \mathrm{M}$ website views per year

At BMC, research is always in progress.

Learn more biomedcentral.com/submissions 